\title{
Physiological responses and expression of VrDREB2A gene at different growth stages of mungbean (Vigna radiata L. Wilczek) under drought stress
}

Hang Thi Thuy Vu ( $\nabla$ vtthang.nh@vnua.edu.vn )

Vietnam National University of Agriculture https://orcid.org/0000-0002-2951-8503

Cham Thi Tuyet Le

Vietnam National University of Agriculture

Ly Thi Pham

Vietnam National University of Agriculture

\section{Research Article}

Keywords: DREB, drought stress, gene expression, plant available water, relative reduction

Posted Date: June 8th, 2021

DOI: https://doi.org/10.21203/rs.3.rs-583427/v1

License: (c) (i) This work is licensed under a Creative Commons Attribution 4.0 International License.

Read Full License 
1 Physiological responses and expression of $\mathrm{VrDREB} 2 \mathrm{~A}$ gene at different growth

2 stages of mungbean (Vigna radiata $\mathbf{L}$. Wilczek) under drought stress

3 Thi Thuy Hang Vu ${ }^{1}$, Thi Tuyet Cham Le ${ }^{1}$, Thi Ly Pham ${ }^{2}$

$4 \quad{ }^{1}$ Faculty of Agronomy, Vietnam National University of Agriculture, Vietnam

$5{ }^{2}$ Undergraduate student of Advanced Crop Science Program, Faculty of Agronomy,

6 Vietnam National University of Agriculture, Vietnam

7 Corresponding author: vtthang.nh@vnua.edu.vn; ORCID: 0000-0002-2951-8503

\section{Abstract}

Mungbean is an important pulse crop and commonly grown in Asia. Drought affects mungbean growth and yield at at different growing stages and various levels through physiological traits and gene expression. In this study, two mungbean cultivars, DX208 and Tam Thanh Hoa, were exposed to drought at the vegetative and flowering stages and assessed for various morphophysiological traits at 8,12,15 and 15 days post withholding water and the plant recovery 7 days after re-watering. Differential expression of $\operatorname{VrDREB} 2 A$ gene was observed in leaf and root of two mungbean cultivars under drought condition. Plants used up water more quickly at the flowering stage than the vegetative stage. Drought adversely affected the plant height, leaf number, aboveground plant biomass and root weight with relative reduction to the control by $4.0-$ $85 \%$. Yield components and individual yield reduced significantly by around $50-60 \%$ compared to the control. Relative expression of $\operatorname{VrDREB} 2 A$ gene was varied, with stronger expression in leaves and roots when drought imposed at the flowering and vegetative stages respectively. Increase in $\operatorname{VrDREB} 2 A$ expression occurred earlier at 8 days compared with 12 days for drought imposed at the flowering and vegetative stages respectively, resulting in more tolerance of plants to drought at the flowering stage. The results indicate that $\operatorname{VrDREB} 2 \mathrm{~A}$ functioned as an important transcriptional activator and might help increase the drought stress tolerance of the mungbean plant at various growing stages. Morphophysiological traits can also be used as indicators in screening mungbean for drought tolerance.

29 Key words: DREB, drought stress, gene expression, plant available water, relative reduction. 
Declarations

32 Funding: The International Foundation of Science, Sweden (IFS) provided the grant for 33 this study

34 Conflicts of interest/Competing interests: Not applicable

35 Availability of data and material: The datasets analysed in the current study are

36 available from the corresponding author on reasonable request.

37 Code availability: Not applicable

38 Authors' contributions: All authors contributed to the study conception and design.

39 Material preparation, data collection and analysis were performed by Thi Thuy Hang Vu,

40 Thi Tuyet Cham Le and Thi Ly Pham. The first draft of the manuscript was written by

41 Thi Thuy Hang Vu and all authors commented on previous versions of the manuscript.

42 All authors read and approved the final manuscript.

43 Conceptualization: Thi Thuy Hang Vu; Methodology: Thi Tuyet Cham Le and Thi Ly

44 Pham; Formal analysis and investigation: Thi Thuy Hang Vu and Thi Tuyet Cham Le;

45 Writing - original draft preparation: Thi Thuy Hang Vu; Writing - review and editing: Thi

46 Thuy Hang Vu, Thi Tuyet Cham Le and Thi Ly Pham.

47 Ethics approval Not applicable

48 Consent to participate: Not applicable

49 Consent for publication: Authors hereby give our consent for the publication of this

50 study to be published in Euphytica.

51 Acknowledgments

52 The first author acknowledges the grant from the International Foundation of

53 Science, Sweden (IFS) for this study. The authors also thank Vietnam National

54 University of Agricultrue, especially Veterinary Clinic of the University for provision of

55 facilities for molercular analysis.

56

57

58 


\section{INTRODUCTION}

Drought is a common abiotic stress that is severe threats to crop growth and food production worldwide and can lead to more than 50\% yield loss (Singh et al. 2015; Nadeem et al. 2019). Drought stress affects the plants at different plant development stages and at various levels of their organization from phenological, morphological, physiological to molecular levels (Ahmad and Prasad 2012; Kaur and Asthir 2017; Nair et al. 2019). Low germination rate, early flowering, flower abscission and young pod abortion are observed throughout plant development stages under water deficit (Ranawake et al. 2012; Bangar et al. 2019; Nadeem et al. 2019). Various morphophysiological indicators such as growth and yield parameters (viz. plant height, leaf number and area, number of pods per plant, number of pods per cluster, number of clusters per plant, number of seeds per pod) and root and shoot characters (viz. root and shoot length, number of roots, root diameter, fresh and dry weight of root and shoot) have been used for screening drought tolerance in mungbean (Prakash et al. 2017; Bangar et al. 2019).

At molecular level, the signaling network and transcriptional regulatory pathways are important to abiotic stress responses (Atkinson and Urwin 2012; Casassola et al. 2013; Yoshida et al. 2014). Various transcription factors (TFs) and their binding sites, the so-called cis-acting elements have been identified as molecular switches of stress-responsive gene expression. Five TF families [bZIP (mainly $A R E B / A B F), D R E B(A P 2 / E R E B P), M Y B / M Y C, N A C$ and $W R K Y)]$ have been shown to be associated with drought tolerance (Joshi et al. 2016). Among those TF families, plant-specific $D R E B$ (dehydration-responsive element binding protein) originally isolated in Arabidopsis (Liu et al. 1998) has been identified, isolated and characterized in different plant species, such as common wheat, rice, maize and soybean (Chen et al. 2007; Joshi et al. 2016). The DREB transcription factor was also reported to be induced by drought (Nakashima et al. 2000; Sakuma et al. 2006; Qin et al. 2007). The roles of the DREB2A gene from Arabidopsis in abiotic stress tolerance have been well characterized (Sakuma et al. 2006) but very limited in legume, especially in mungbean. In cowpea, $V u D R E B 2 A$ was induced by drought and salt stresses, and heterologous expression of $V u D R E B 2 A$ resulted in significant drought stress tolerance in Arabidopsis (Sadhukhan et al. 2014). In soybean, two GmDREB2A homologs (GmDREB2A;1 and GmDREB2A;2) were identified (Mizoi et al. 2013). Although the peptide sequences are 
very similar to each other, the induction of $G m D R E B 2 A ; 2$ was stronger than that of GmDREB2A;1 and improved stress tolerance in Arabidopsis (Mizoi et al. 2013). The DREB2A genes from different species, such as common wheat (Egawa et al. 2006), pearl millet (Agarwal et al. 2007) and chrysanthemum (Liu et al. 2008) that caused physiological variations, were also overexpressed in Arabidopsis thaliana and improve stress tolerance under drought, salt and freezing stresses in transgenic plants. However, similar studies are very limited in mungbean, and the molecular mechanisms controlling plant tolerance to abiotic stress such as drought remains largely unknown.

Mungbean (Vigna radiata L. Wilczek) is the third most important pulse crop after chickpea and pigeon pea and predominantly grown across Asia (Nair et al. 2013, 2019). The mungbean, a short growth duration crop, is grown widely under rainfed conditions and an ideal legume for catch cropping, intercropping, relay cropping and soil nutrient improvement but still considered as an underutilized crop. Due to uneven temporal and spatial distribution of rainfall, the crop often suffers from water stress at any growth stages in its growing cycle leading to reduced growth and productivity. In addition, being grown on marginal lands and under hot climate conditions (Nair et al. 2013; van Zonneveld et al. 2020), mungbean is largely considered as a moderately drought tolerant, and this distinctive characteristic makes it a valuable tropical legume for studying the molecular tolerance mechanisms of various abiotic stresses, particularly drought (Kim et al. 2004, 2015). Recently, the $\operatorname{VrDREB} 2 A$ gene with conserved AP2 domains and transactivation ability was isolated from mungbean by Chen et al. (2016). The expression of the $\operatorname{VrDREB} 2 A$ gene is induced by drought, high salt concentrations and abscisic acid treatment at seedling stage. Moreover, the overexpression of $\operatorname{VrDREB} 2 A$ in transgenic Arabidopsis activates the expression of downstream genes, resulting in enhanced tolerance to drought and high-salt stresses and no growth retardation (Chen et al. 2016). This indicates that $\operatorname{VrDREB} 2 A$ functions as an important transcriptional activator and may help increase the abiotic stress tolerance of the mungbean plant. However, it has not been known yet how the expression of $\operatorname{VrDREB} 2 \mathrm{~A}$ would affect mungbean under water deficit at different growth stages, viz. vegetative and flowering stages.

Therefore, a better understanding of the responses of mungbean under different drought stress conditions in aspects of physiological traits and gene expression is required for mungbean improvement. Within this aim, the growth and the associated 
expression of $\operatorname{VrDREB} 2 \mathrm{~A}$ gene in response to drought stress at the vegetative and

126 flowering stages in mungbean cultivars of Vietnam were studied.

\section{MATERIALS AND METHODS}

\section{Plant materials and drought imposition}

Plant materials included two mungbean cultivars, DX208 (improved cultivar,

130 G1) and Tam Thanh Hoa (landrace, G2), obtained from the Plant Resources Center of

Vietnam Academy of Agriculultural Sciences. These two cultivars are suitable to dry and sandy soils so that they are somewhat moderately to highly drought tolerance

133 (Nguyen et al. 2017). Agronomy, Vietnam National University of Agriculture from May to September, 2019 (summer season). The seeds were sown in $30 \mathrm{x} 40 \mathrm{~cm}$ in diameter and height pots, each pot was left with two plants. The pots were filled with substrate containing $6.5 \mathrm{~kg}$ alluvial soil mixed with fine sand $(1: 1, \mathrm{v} / \mathrm{v})$ and $0.5 \mathrm{~kg}$ Song Gianh microbial-organic fertilizer containing $0.45 \mathrm{~g}$ phosphorus and kept in greenhouse under temperature condition $32{ }^{\circ} \mathrm{C}$ with regular watering every day before water was withheld in drought treated plants. The experiment was arranged in a randomized complete block with two replications with four pots each.

For drought imposition at vegetative stage, the plants were fully watered until 20 days after emergence ( 2 true-leaf stage) and then water was witheld for 8, 12, 15 and 20 days. For drought imposition at flowering stage, the plants were fully watered for 33 days after emergence (first flower bud appearance) and the drought was imposed for duration times similar to those at vegetative stage. The control plants were fully watered throughout the experiment.

The recovery experiment was set up separately with the same cultural prepation and drought imposed at vegetative and flowering stages, and with two replications (4 plants per replication). After 20 days without water, all pots were simultaneously watered to evaluate the recovery.

\section{Evaluation of plant growth charactristics}

At the setup of the experiment, the pots were saturated with water and weighted. All pots were weighted weekly to measure the water used by plants. After 8, 12, 15 or 20 days without water, all pots were also weighted to measure the water used. The 
80

characteristics measured at $8,12,15$ and 20 days post drought exposure included plant height, leaf number, the fresh and dry weight of the above-ground mass and roots.

The recovery measurements included plant height, leaf number, yield components and individual yield $\left(\mathrm{g}\right.$ plant $\left.^{-1}\right)$. The recovery was scored using $1-4$ scale: (1) plant death plant; (2) less than $30 \%$ wilting leaf recovered; (3) more than $60 \%$ wilting leaf recovered; (4) completely recovery with more than $>90 \%$ wilting leaf recovered.

\section{RNA extraction, synthesis of cDNA and qRT-PCR reaction}

The leaf and root samples were harvested from at 8, 12, 15 and 20 days post drought exposure. The samples were cleaned, wrapped in alumininum foil and immediately immerged in liquid nirogen and stored at $-80^{\circ} \mathrm{C}$ freezer before RNA extraction.

RNA was isolated from leaf and root samples using Easy-spin ${ }^{\mathrm{TM}}$ IIp Plant RNA Extraction Kit (Intron Bio-Korea). cDNA was amplified using reverse transcription PCR (RT-PCR) with MLV Reverse Transcriptase (Promega, Tokyo, Japan). The primers of $\operatorname{VrDREB} 2 A$ gene and the reference gene VrActin (Chen et al. 2016) were used for qRT-PCR reaction (Table 1). The Master mix for qRT-PCR was accompanied by the kit GoTaq(R) qPCR Master Mix (Promega, A6001) containing $0.1 \mu \mathrm{g} / \mu 1$ master mix, $1.6 \times 10^{-3} \mu \mathrm{g} / \mu \mathrm{l}$ primer of each kind, $0.08 \mu \mathrm{g} / \mu \mathrm{l} \mathrm{cDNA}$ and water.

The leaf and root samples of the control plants (fully watered) of the cultivar DX208 were included in each qRT-PCR reaction as reference to enable the calculation of the relative gene experession under drought stress.

Table 1. Primer sequences used for qRT-PCR reaction

\begin{tabular}{lll}
\hline Gene & Primer & Sequence \\
\hline \multirow{2}{*}{ VrDREB2A } & $\operatorname{VrDREB2A-F}$ & 5'-CTGCTCTTGCTTATGATGAA-3' \\
& $\operatorname{VrDREB2A-R}$ & 5'-ATGTAGTGGTAGTAGTAGTAGTG-3' \\
\multirow{2}{*}{ VrActin } & VrActin- $F$ & 5'-TCCACGAGACAACATATAACT-3' \\
& VrActin- $R$ & 5'-TCCTTGCTCATCCTATCAG-3' \\
\hline
\end{tabular}

The thermal RT-PCR cycle was run as follows: $95^{\circ} \mathrm{C}$ for $1 \mathrm{~min}, 40$ cycles $95^{\circ} \mathrm{C}$ in 15 seceonds, $60^{\circ} \mathrm{C}$ for $1 \mathrm{~min}$, the curve was noted from $55-95^{\circ} \mathrm{C}, 72{ }^{\circ} \mathrm{C}$ in 18 
201

202

seconds. After the cycle terminated, the process was transferred to $72{ }^{\circ} \mathrm{C}$ for 7 min and the samples were kept at $12{ }^{\circ} \mathrm{C}$. The qRT-PCR was done with two technical replications for each sample to ensure the reliability and homogeneity. A reference sample was selected arbitrary from any RNA sample in each qRT-PCR.

\section{Statistical analysis}

Plant available water and expression of physiological traits

The plant available water (PAW) was deterimed as follows:

$$
\operatorname{PAW}(\%)=\frac{W_{t}-W_{i}}{W_{s}-W_{i}} \times 100
$$

Where: $W_{t}$ is the pot weight at $8,12,15$ and 20 days after drought exposure $W_{S}$ is the weight of pot saturated with water $W_{i}$ is the weight of pot initially filled with substrate

The relative differences $(\%)$ of evaluated traits between the treatment (imposed drought at vegetative and flowering stages) and control were used for analysis:

$$
\text { Relative difference }(\%)=\frac{P_{t}-P_{c}}{P_{c}} \times 100
$$

Where: $P_{t}$ and $P_{c}$ are the trait in drought and control treatment respectively;

The drought resistance index (DRI) of mungbean cultivars was calculated by formula presented by Fischer and Maurer (1978):

$$
\mathrm{DRI}=\frac{Y_{t} / Y_{c}}{\overline{\mathrm{Y}}_{t} / \overline{\mathrm{Y}}_{c}}
$$

Where: $Y_{t}$ and $Y_{c}$ are the grain yield in drought and control treatment respectively;

$\overline{\mathrm{Y}}_{t}$ and $\overline{\mathrm{Y}}_{c}$ are the average values of all examined genotypes of grain yield in drought and control treatment respectively.

ANOVA analysis was used to evaluate the differences in physiological traits between varieties exposed to drought at different stages (vegetative and flowering) and at different times $(8,12,15$ and 20 days after withholding water). The mean values were calculated from replicates.

\section{Relative expression of $\operatorname{VrDREB} 2 \mathrm{~A}$}

The relative expression of $\operatorname{VrDREB} 2 A$ was presented by $\mathrm{R}=2^{-\Delta \Delta \mathrm{Ct}}$ based on housekeeping gene and calibator as described by Livak and Schmittgen (2001). $2^{-\Delta \Delta C t}$ is 
212 the relative gene expression of the test sample in comparison with the control. In this

213 study, the relative gene expression was determined based on the expression of

$214 \operatorname{VrDREB} 2 A$ in leaves and roots to the reference gene VrActin and to the calibrator (leaf sample of G1 under full watering condition) using the following equation:

218 Where:

\begin{tabular}{ccccccc}
\hline \multirow{2}{*}{$\begin{array}{c}\text { Drought } \\
\text { stage }\end{array}$} & Cultivar & \multicolumn{3}{c}{ PAW (\%) post drought exposure } & \multirow{2}{*}{$\begin{array}{c}\text { Reduction } \\
\text { of PAW }\end{array}$} \\
\cline { 3 - 6 } & & 8 days & 12 days & 15 days & 20 days & (\%/day) \\
\hline Vegetative & G1 & 63.3 & 45.4 & 29.0 & 1.0 & 5.03
\end{tabular}




\begin{tabular}{ccccccc} 
stage & G2 & 55.0 & 38.8 & 17.1 & 0.5 & 5.06 \\
\hline $\begin{array}{c}\text { Flowering } \\
\text { stage }\end{array}$ & G1 & 36.8 & 10.4 & 3.8 & 0.3 & 4.35 \\
\hline
\end{tabular}

\section{Effect of drought on the growth and development of mungbean}

The analysis of variance for drought imposition stage and duration time showed that drought significantly affected plant growth, such as plant height and leaf number as compared with the control. Increased drought duration time adversely reduced plant growth (Table 3; Fig. 1). When imposing drought at vegetative stages for 8 - 20 days, the relative reduction in plant height increased from 14.6 to $43.4 \%$ for $\mathrm{G} 1$ and from 5.3 to $45.2 \%$ for G2. Similar parttern was also observed for the relative reduction in plant height caused by drought at flowering stage (Table 3a). The relative reduction in the number of leaves compared to the control at 8-20 days varied from 5.1 to $38.5 \%$ and from 3.9 to $25.0 \%$ for drought imposed at vegetative and flowering stages respectively (Table 3b). In general, relative reduction in plant growth was somewhat higher in G1.

Drought stress at vegetative as well as flowering stages significantly affected the accumulation of plant biomass (Fig. 1). The fresh and dry plant weight, and fresh root weight significantly reduced when exposed to drought at both vegetative and flowering stage (Table $3 \mathrm{c}-\mathrm{e}$ ). As soon as water was withheld, the plant and root fresh weights dramatically reduced as compared to the control, with the rate of $5.3 \%$ to $16.1 \%$ at 8 days. The reduction was proportional with the time of exposure to drought with high relative reduction, even up to $80 \%$ as observed for fresh root weight at 20 days.

Table 3. Relative reduction $(\%)^{\mathrm{a}}$ of measured mungbean characters as influenced by drought in relation to fully watered plants

\begin{tabular}{|c|c|c|c|c|c|c|c|c|c|}
\hline \multirow{2}{*}{$\begin{array}{l}\text { Measured } \\
\text { characters }\end{array}$} & \multirow{2}{*}{ Cultivar } & \multicolumn{4}{|c|}{$\begin{array}{c}\text { Duration of drought exposure } \\
\text { at vegetative stage }\end{array}$} & \multicolumn{4}{|c|}{$\begin{array}{c}\text { Duration of drought } \\
\text { exposure at flowering stage }\end{array}$} \\
\hline & & $\begin{array}{c}8 \\
\text { days }\end{array}$ & $\begin{array}{c}12 \\
\text { days }\end{array}$ & $\begin{array}{c}15 \\
\text { days }\end{array}$ & $\begin{array}{c}20 \\
\text { days }\end{array}$ & $\begin{array}{c}8 \\
\text { days }\end{array}$ & $\begin{array}{c}12 \\
\text { days }\end{array}$ & $\begin{array}{c}15 \\
\text { days }\end{array}$ & $\begin{array}{c}20 \\
\text { days }\end{array}$ \\
\hline \multirow{2}{*}{ a. Plant height } & G1 & -14.6 & -24.2 & -33.6 & -43.4 & -17.9 & -32.6 & -35.6 & -35.5 \\
\hline & $\mathrm{G} 2$ & -5.3 & -29.3 & -34.7 & -45 & -8.7 & -13.1 & -13.2 & -17.1 \\
\hline \multirow{2}{*}{$\begin{array}{l}\text { b. Leaf } \\
\text { number }\end{array}$} & G1 & -8.6 & -18.8 & -33.3 & -38.5 & -13.2 & -15.6 & -19.4 & -25.0 \\
\hline & $\mathrm{G} 2$ & -5.1 & -14.3 & -16.7 & -28.6 & -3.9 & -5.3 & -7.7 & -7.7 \\
\hline \multirow{2}{*}{$\begin{array}{l}\text { c. Fresh plant } \\
\text { weight }\end{array}$} & G1 & -32.8 & -45.5 & -65.3 & -75.8 & -14.6 & -36.7 & -47.5 & -67.1 \\
\hline & $\mathrm{G} 2$ & -28.6 & -46.4 & -56.1 & -79.5 & -5.3 & -8.0 & -43.8 & -66.3 \\
\hline \multirow{2}{*}{$\begin{array}{l}\text { d. Fresh root } \\
\text { weight }\end{array}$} & G1 & -57.9 & -67.7 & -74.6 & -84.8 & -16.1 & -27.3 & -39.0 & -80.8 \\
\hline & $\mathrm{G} 2$ & -41.7 & -62.5 & -73.9 & -83.8 & -12.0 & -27.3 & -38.9 & -63.3 \\
\hline
\end{tabular}




\begin{tabular}{llllllllll} 
e. Dry plant & G1 & -22.9 & -37.6 & -65.4 & -66.0 & -7.9 & -39.9 & -40.3 & -42.9 \\
weight & G2 & -24.0 & -42.3 & -43.0 & -76.8 & -3.2 & -9.1 & -37.9 & -42.0 \\
\hline
\end{tabular}

${ }^{a}$ Negative values indicate the relative reduction (\%) of the measured traits in

259 drought treatment to the control

260

261 Fig. 1 Severe symptoms of plants and roots after 20 days exposed to drought at the

262 flowering stage on two mung bean cultivars, DX208 (A) and Tam Thanh Hoa (B) (left:

263 control, right: drought stress)

\section{Effect of drought on plant recovery}

At 20 days post-drought exposure, mung bean plants apparently showed wilting,

266 leaf dropping and death. After rewatering, only those leaves that remained on the plant

267 recovered, contributing to the regrowth of the plants. For drought imposed at the

268 vegetative stage, plant height increased by $7.6-22.5 \%$ and leave number increased by

$2697.5-31.3 \%$ (by $0.4-1.3$ leaves) compared to the point prior re-watering (Table 4).

270 This recovery trends were not observed for drought imposed at the flowering stage, with

271 the slightly increase in plant height $(6.2-8.0 \%)$ but reduction in leaf number $(18.8-$

272 25.5\%). However, in comparison with the control plants, the growth characteristics of

273 stressed plants remained much lower regardless of stages exposed to drought, with

274 ranges of $24.5-47.2 \%$ for plant height and of $10.5-37.6 \%$ for leaf number. The

275 recovery scores of cultivar G2 were higher than those of cultivar G1.

276 Table 4. Recovery of mungbean plants 7 days after rewatering ${ }^{\mathrm{b}}$

\begin{tabular}{|c|c|c|c|c|c|c|c|c|}
\hline \multirow{2}{*}{$\begin{array}{l}\text { Drought } \\
\text { stage }\end{array}$} & \multirow[t]{2}{*}{ Cultivar } & \multicolumn{2}{|c|}{$\begin{array}{c}\text { In relation to } \\
\text { control }(\%)\end{array}$} & \multicolumn{2}{|c|}{$\begin{array}{l}\text { In comparison } \\
\text { to point prior } \\
\text { re-watering }(\%)\end{array}$} & \multirow{2}{*}{$\begin{array}{c}\text { Plant } \\
\text { height } \\
(\mathrm{cm})\end{array}$} & \multirow{2}{*}{$\begin{array}{c}\text { Leaf } \\
\text { number }\end{array}$} & \multirow{2}{*}{$\begin{array}{c}\text { Recovery } \\
\text { score }\end{array}$} \\
\hline & & $\begin{array}{c}\text { Plant } \\
\text { height }\end{array}$ & $\begin{array}{c}\text { Leaf } \\
\text { number }\end{array}$ & $\begin{array}{c}\text { Plant } \\
\text { height }\end{array}$ & $\begin{array}{c}\text { Leaf } \\
\text { number }\end{array}$ & & & \\
\hline Vegetative & G1 & -47.2 & -37.6 & 22.5 & 31.3 & 27.0 & 5.3 & 2.8 \\
\hline stage & $\mathrm{G} 2$ & -36.5 & -17.0 & 7.6 & 7.5 & 32.0 & 5.4 & 3.3 \\
\hline Flowering & G1 & -37.5 & -14.1 & 8.0 & -18.8 & 34.3 & 4.9 & 2.0 \\
\hline stage & $\mathrm{G} 2$ & -24.5 & -10.5 & 6.2 & -25.5 & 38.5 & 4.5 & 2.2 \\
\hline
\end{tabular}

$277{ }^{b}$ Negative values indicate the relative reduction (\%) of the measured traits in drought

278 treatment to either control or to the point prior re-watering; The positive indicates the

279 relative increase (\%) after 7 days of recovery compared to the point prior re-watering. 
281 the components of yield, viz. number of pod clusters, number of pods per plant, pod

282 weight and plant individual yield (Table 5). The relative reduction of yield components

283 was rather high in comparison witth the control, ranging from around $28-60 \%$,

284 especially the number of pods and individual yield, but lower in cultivar G2. The pod

285 cluster and pod number per plant in both cultivars reduced by $28.6-55.2 \%$ and $30.0-$

$28658.1 \%$, respectively, leading to reduce pod weight by $53.5-62.2 \%$ and plant individual

287 yield by $49.6-56.6 \%$ in relation to the control. It appeared that cultivar G2 was better

288 tolerant to drought than cultivar G1 as evidenced by higher plant yields (2.08 and $2.31 \mathrm{~g}$

289 plant $^{-1}$ ) and drought resistance indices (1.024 and 1.069) (Table 5).

290 Table 5. Effects of drought at vegetative and flowering stage on yield components,

291 individual yield relative to control and drought resistance index (DRI) ${ }^{\mathrm{a}}$

\begin{tabular}{|c|c|c|c|c|c|c|c|}
\hline \multirow{2}{*}{$\begin{array}{l}\text { Drought } \\
\text { stage }\end{array}$} & \multirow[b]{2}{*}{ Cultivar } & \multicolumn{4}{|c|}{ Reduction (\%) in relation to control } & \multirow{2}{*}{$\begin{array}{c}\text { Plant yield } \\
(\text { g plant-1) } \pm \text { s.e }\end{array}$} & \multirow[b]{2}{*}{ DRI } \\
\hline & & $\begin{array}{c}\text { Pod cluster } \\
\text { number }\end{array}$ & $\begin{array}{c}\text { Pod } \\
\text { number }\end{array}$ & $\begin{array}{c}\text { Pod } \\
\text { weight }\end{array}$ & $\begin{array}{l}\text { Plant } \\
\text { yield }\end{array}$ & & \\
\hline Vegetative & G1 & -55.2 & -57.9 & -56.3 & -56.6 & $1.68 \pm 0.27$ & 0.972 \\
\hline stage & $\mathrm{G} 2$ & -46.4 & -30.0 & -53.5 & -53.3 & $2.08 \pm 0.72$ & 1.024 \\
\hline Flowering & G1 & -37.1 & -58.1 & -62.2 & -55.7 & $1.69 \pm 0.47$ & 0.980 \\
\hline stage & G2 & -28.6 & -47.1 & -54.1 & -49.6 & $2.31 \pm 0.47$ & 1.069 \\
\hline
\end{tabular}

$292{ }^{a}$ Negative values indicate the relative reduction (\%) of the measured traits in

293 drought treatment to the control

294 Relative expression level of $\operatorname{VrDREB} 2 A$ gene

295 The t-test indicated that there was difference in gene expression of $\operatorname{VrDREB} 2 \mathrm{~A}$

296 between normal and drought conditions at both vegetative and flowering stages (Fig. 2

$297 \& 3)$.

298 The reponse to drought set in differently in mungbean cultivars, time point and 299 duration, and stage of plant growth when water was witheld. Generally, at 12 and 8 days 300 on wards after drought exposure at the vegetative and flowering stages respectively, the 301 relative gene expression levels in leaves and roots were higher than the control plants 302 (Fig. 2). At vegetative state, the relative expression level of $\operatorname{VrDREB} 2 \mathrm{~A}$ in root started 303 to increase significantly early at 8 days post-drought exposure earlier in cultivar G1 (R $304=2.689)$ and at 20 days after withholding water $(\mathrm{R}=2.041)$. Significant expression was 305 also found leaves of cultivar $\mathrm{G} 2$ at 15 days $(\mathrm{R}=3.137)$ and in roots $(\mathrm{R}=2.925)$ at 20 306 days after withholding water. 
Fig. 2 Relative expression of $\operatorname{VrDREB} 2 \mathrm{~A}$ gene in leaves and roots of two mung bean cultivars, DX208 (G1) and Tam Thanh Hoa (G2), exposed to drought at the vegetative stage for (a) 8, (b) 12, (c) 15, (d) 20 days in comparison with the control

Unlike drought exposure at vegetative stage, the relative expession level of $\operatorname{VrDREB} 2 A$ when plants exposed to drought at flowering stage was ealier and higher in comparison to the control both in leaves and roots (Fig. 3). Significant expression levels in leaves were obsevered for both G1 and G2 throughout $8-20$ days after withholding water ( $\mathrm{R}$ varied from 0.901 to 4.780 ). Significant expression levels in roots for $\mathrm{G} 1$ and G2 were identified on 8 days exposure to drought with $\mathrm{R}$ of 2.271 and 2.855 respectively.

Fig. 3 Relative expression of VrDREB2A gene in leaves and roots of two mung bean cultivars, DX208 (G1) and Tam Thanh Hoa (G2), exposed to drought at the flowering stage for (a) 8, (b) 12, (c) 15, (d) 20 days in comparison with the control

\section{DISCUSSION \& IMPLICATION}

The larger reduction of PAW at flowering stage can be attributable to larger plant size (viz. higher plant height and leaf number) at the point of water withholding as compared with that at vegetative stage (Table 2). As results, plants used up water more quickly at the flowering stage than at the vegetative stage, with PAW reaching to $\leq 5 \%$ by 15 days. Thus, mungbean can stand for drought up to $15-20$ days upon the growth stages that drought occurs. Some studies also applied this range of days for evaluation of drought tolerance in mungbean, such as Iseki et al. (2018) (7 - 22 days) and Bangar et al. (2019) (15 days), suggesting the maximum time mungbean can stand for without irrigation.

Drought significantly affects plant growth regarldess of growth stages. The longer the exposure to drought the higher is the reduction of physiological traits, such as plant height, leaf number, above-ground plant biomass and root weight (Table 3). The relative reduction in those physiological traits can be varied largely from $4.0-85.0 \%$, which results in large relative reduction in yield component traits and individual yield (mostly around 50-60\%) (Table 5). Therefore, drought affects adversely plant yield as seen by the reduced number of pods per plant, number of pod clusters per plant, pod weight and individual yield at both the vegetative and flowering stages. Other traits such 
as relative water content, membrane stability index, chlorophyl content, protein and proline contents, and harvest index were also found to significantly reduced by $1.0-$ 80\% compared to the control (Bangar et al. 2019; Nadeem et al. 2019). Fathy et al. (2018) and Nadeem et al. (2019) reported yield loss in the range of $31-60 \%$ at flowering and $26 \%$ at post flowering/podding stages in mungbean due to drought stress. The vegetative stage was more sensitive to drought stress than the flowering stage with higher relative reduction in plant height and leaf number after $8-20$ days post withholding water and 7 days of recovery. This phenomenon was also observed in previous studies (Allahmoradi et al. 2011; Ranawake et al. 2012; Ratnasekera and Subhashi 2015; Bangar et al. 2019) and is probably due to the low water absorption capacity during the vegetative stage.

The re-watering time point is critical for recovery of plants. In this experiment, plants were rewatered at 20 days after exposure to drought, which is the common duration of drought that plants can stand for. The common symptoms of plants exposed to drought are leaf wilting, rolling and even dropping, and wilting growing tips ( $\mathrm{Vu}$ et al. 2015). Therefore, the more remnant leaves on the plants, the more ability for plants to recover after re-watering. Plants exposed to drought at the vegetative stage were able to increase their height and leaf number after re-watering. However, the leaf number was reduced after recovery 7 days since dropping and death of lower leaves near the ground (Table 4). In addition, in this experiment, cultivar G2 seemed to be more drought tolerant than cultivar G1 with smaller relative reduction in physiological traits, and higher individual yields, recovery scores and drought resistance indices.

372 lasted from 8 to 20 days (Fig. 3). At 1-week-old seedling stage, expression of 
$\operatorname{VrDREB} 2 A$ in response to drought began to increase within $1 \mathrm{~h}$ (around 6-fold) and continued to increase after $3 \mathrm{~h}$ (around 13-fold) (Chen et al. 2016). Thus, these results were in line with study by Chen et al. (2016) that the activation of expression of $\operatorname{VrDREB} 2 A$ gene was induced by abiotic stresses, including drought. The earlier and longer activation of $\operatorname{VrDREB} 2 \mathrm{~A}$ gene at the flowering stage can explain the more tolerance of mungbean plants to drought than at the vegetative stage. However, the increase in relative levels of $\operatorname{VrDREB} 2 \mathrm{~A}$ expression in this study are not as high as in other studies on DREB when plants are exposed to abiotic stresses. This might be correlated to the time plant samples should be collected and analyzed for gene expression. For example, relative expression levels of $\operatorname{VrDREB} 2 A$ were 6 - 13-fold after $1-3 \mathrm{~h}$ post drought treatment and after $1-24 \mathrm{~h}$ post salt treatment (Chen et al. 2016). ThDREB expression levels in root and stem of Tamarix hispida were around 369-fold of control under $\mathrm{NaCl}$ stress for $6 \mathrm{~h}$ and 6-fold of control under PEG stress for $12 \mathrm{~h}$ (Yang et al. 2017). The expression of other drought tolerant related gene in mungbean,

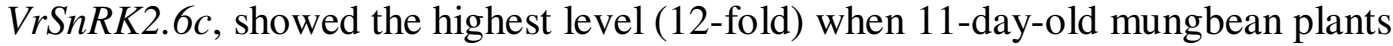
exposed to 3 days withholding water (Fatima et al. 2020). The upregulation of $\operatorname{VrDREB}$ in drought tolerant mungbean was also observed during recovery from drought and higher in leaf than in petiole (Meena et al. 2021). In addition, the increase in gene expression in plants is not always the cases when plants are exposed to drought. The expression of drought tolerance gene might occur in other plant organs depending on plant species. For instance, the expression of GmHKO6 (encoded for protein homologous to CK12/AHK5 in Arabidopsis) in soybean reduced in roots but increased in shoots in plants exposed to water stress. In contrast, drought stress led to increased expression of GmRR34 in both soybean roots and shoots (Hoang et al. 2014).

The results of the present study clearly show that water stress adversely influenced plant growth and yield of mungbean in different manners as reported in various studies (Blum 1996; Sanchez et al. 2012; Iseki et al. 2018). Under water stress the expression of $\operatorname{VrDREB} 2 A$ gene was activated to combat plant water deficit. The expression level increased significantly when water stress occurs at flowering stage and in leaves. In relation to the genotype, the drought resistant cultivar showed stronger $\operatorname{VrDREB2A}$ expression. Therefore, this knowledge of physiological responses and gene expression in mungbean under drought condition might contribute to ongoing studies of drought resistance in mungbean. 


\section{REFERENCES}

Agarwal P, Agarwal PK, Nair S, Sopory SK, Reddy MK (2007) Stress-inducible $D R E B 2 A$ transcription factor from Pennisetum glaucum is a phosphoprotein and its phosphorylation negatively regulates its DNA-binding activity. Mol Genet Genom 277:189-198. https://doi.org/10.1007/s00438-006-0183-z

Ahmad P, Prasad MNV (2012) Abiotic stress responses in plants: Metabolism, Productivity and Sustainability. Springer, New York

Allahmoradi P, Ghobadi M, Taherabadi S, Taherabadi S (2011) Physiological aspects of mungbean (Vigna radiata $\mathrm{L}$.) in response to drought stress. International Conference on Food Engineering and Biotechnology - ICFEB 2011 Bangkok, Thailand 9, pp 272-275

Atkinson NJ, Urwin PE (2012) The interaction of plant biotic and abiotic stresses: from genes to the field. J Exp Bot 63:3523-3543. https://doi.org/10.1093/jxb/ers100

Bangar P, Chaudhury A, Tiwari B, Kumar S, Kumari R, Bhat KV (2019) Morphophysiological and biochemical response of mungbean [Vigna radiata (L.) Wilczek] varieties at different developmental stages under drought stress. Turk. J. Biol 43: 58-69. https://doi:10.3906/biy-1801-64

Blum A (1996) Crop responses to drought and the interpretation of adaptation. Plant Growth Regul 20:135-148. https://doi.org/10.1007/BF00024010

Casassola A, Brammer SP, Chaves MS, Martinelli JA, Grando MF, Denardin ND (2013) Gene expression: A review on methods for the study of defense-related gene differential expression in plants. Am. J. Plant Sci 4:64-73

Chen H, Liu L, Wang L, Wang S, Cheng X (2016) VrDREB2A, a DREB-binding transcription factor from Vigna radiata, increased drought and high-salt tolerance in transgenic Arabidopsis thaliana. J. Plant Res 129:263-273. https://doi.org/10.1007/s10265-015-0773-0

Chen M, Wang Q-Y, Cheng X-G, Xu Z-S, Li L-C, Ye X-G, Xia L-Q, Ma Y-Z (2007) GmDREB2, a soybean DRE-binding transcription factor, conferred drought and high-salt tolerance in transgenic plants. Biochem Biophys Res Commun 353: 299-305. https://doi.org/10.1016/j.bbrc.2006.12.027 
Egawa C, Kobayashi F, Ishibashi M, Nakamura T, Nakamura C, Takumi S (2006) Differential regulation of transcript accumulation and alternative splicing of a DREB2 homolog under abiotic stress conditions in common wheat. Genes Genet Syst 81:77-91. https://doi.org/10.1266/ggs.81.77

Fathy NE, Ismail SM, Basahi JM (2018) Optimizing mungbean productivity and irrigation water use efficiency through the use of low waterconsumption during plant growth stages. Legume Res 41:108-113. https://doi.org/10.18805/lr.v40i04.9014

Fatima A, Khan MJ, Awan HM, Akhtar MN, Bibi N, Sughra K, Khan MR, Ahmad R, Ibrahim M, Hussain JS, Sadiq I (2020) Genome-wide identification and expression analysis of $S n R K 2$ gene family in mungbean (Vigna radiata) in response to drought stress. Crop and Pasture Sci 71:469-476. https://doi.org/10.1071/CP19392

Fischer R, Maurer R (1978) Drought resistance in spring wheat cultivars. I. Grain yield responses. Aust. J. Agric. Res 29:897-912. https://doi.org/10.1071/AR9780897

Hoang TLX, Nguyen HTD, Nguyen BATu, Nguyen PT (2014) Examination of the expression of GmHKO6 và GmRR34 genes under water deficit in two soybean cultivars, MTD777-2 and DT20. J. Biol 36:232-236 (in Vietnamese).

Iseki K, Takahashi Y, Muto C, Naito K, Tomooka N (2018) Diversity of drought tolerance in the genus Vigna. Front. Plant Sci 9: 729. https://doi.org/10.3389/fpls.2018.00729

Joshi R, Wani SH, Singh B, Bohra A, Dar ZA, Lone AA, Pareek A, Singla-Pareek SL (2016) Transcription factors and plants response to drought stress: current understanding and future directions. Front. Plant Sci 7:1029. http://doi.org/10.3389/fpls.2016.01029.

Kaur G, Asthir B (2017) Molecular responses to drought stress in plants. Biolgia Plantarum 61:201-209. https://doi.org/10.1007/s10535-016-0700-9

Kim SK, Nair RM, Lee J, Lee S-H (2015) Genomic resources in mungbean for future breeding programs. Front. Plant Sci 6:626. https://doi.org/10.3389/fpls.2015.00626

Kim YJ, Kim JE, Lee JH, Lee MH, Jung HW, Bahk YY, Hwang BK, Hwang I, Kim 
WT (2004) The Vr-PLC3 gene encodes a putative plasma membrane-localized phosphoinositide-specific phospholipase $\mathrm{C}$ whose expression is induced by abiotic stress in mungbean (Vigna radiata L.). FEBS Lett 556:127-136. https://doi.org/10.1016/S0014-5793(03)01388-7

Liu L, Zhu K, Yang Y, Wu J, Chen F, Yu D (2008) Molecular cloning, expression profiling and trans-activation property studies of a DREB2-like gene from chrysanthemum (Dendranthema vestitum). J Plant Res 121:215226. https://doi.org/10.1007/s10265-007-0140-x

Liu Q, Kasuga M, Sakuma Y, Abe H, Miura S, Yamaguchi-Shinozaki K, Shinozaki K (1998) Two transcription factors, DREB1 and DREB2, with an EREBP/AP2 DNA binding domain separate two cellular signal transduction pathways in drought- and low temperature-responsive gene expression, respectively, in Arabidopsis. Plant Cell 10:1391-1406. https://doi.org/10.1105/tpc.10.8.1391

Livak KJ, Schmittgen TD (2001) Analysis of relative gene expression data using realtime quantitative PCR and the 2(-Delta Delta C(T)) method. Methods 25:402408. https://doi.org/10.1006/meth.2001.1262

Meena SK, Pandey R, Sharma S, Gayacharan Vengavasi K, Dikshit HK, Siddique KHM, Singh MP (2021) Cross tolerance to drought and low phosphorus stress in mungbean is regulated by improved antioxidant capacity, biological $\mathrm{n} 2$-fixation, and differential transcript accumulation. Research Square. https://doi.org/10.21203/rs.3.rs-226221/v1 (under review).

Mizoi J, Ohori T, Moriwaki T, Kidokoro S, Todaka D, Maruyama K et al (2013) GmDREB2A; 2 a canonical dehydration-responsive element-binding protein2-type transcription factor in soybean, is posttranslationally regulated and mediates dehydration-responsive element-dependent gene expression. Plant Physiol. 161:346-361. https://doi.org/10.1104/pp.112.204875

Nadeem M, Li J, Yahya M, Sher A, Ma C, Wang X, Qiu L (2019) Research progress and perspective on drought stress in legumes: a review. Int. J. Mol. Sci 20:2541. https://doi.org/10.3390/ijms20102541

Nair R, Schafleitner R, Kenyon L, Srinivasan R, Easdown W, Ebert AW, Hanson P (2013) Genetic improvement of mungbean. SABRAO Journal of Breeding and 
Nair RM, Pandey AK, War AR, Hanumantharao B, Shwe T, Alam AKMM, Pratap A, Malik SR, Karimi R, Mbeyagala EK, Douglas CA, Rane J, Schafleiner R (2019) Biotic and abiotic constraints in mungbean production - Progress in genetic improvement. Front. Plant Sci 10:1340. https://doi.org/10.3389/fpls.2019.01340

Nakashima K, Shinwari ZK, Sakuma Y, Seki M, Miura S, Shinozaki K, YamaguchiShinozaki K (2000) Organization and expression of two Arabidopsis DREB2 genes encoding DRE-binding proteins involved in dehydration- and highsalinity-responsive gene expression. Plant Mol Biol 42:657-665. https://doi.org/10.1023/A:1006321900483

Nguyen TA, Vu DH, Nguyen TC (2017) Assessment and selection of mungbean varieties suitable for the coast sand land of Thanh Hoa province. Journal of Agriculture and Rural Development 19: 44-49 (In Vietnamese).

Prakash M, Sunilkumar B, Sathiyanarayanan G, Gokulakrishnan J (2017) Screening for drought tolerance in mungbean. Legume Research 40 (3): 423-428. https://doi.org/10.18805/lr.v0iOF.1104

Qin QL, Liu JG, Zhang Z, Peng RH, Xiong AS, Yao QH, Chen JM (2007) Isolation, optimization, and functional analysis of the cDNA encoding transcription factor OsDREB1B in Oryza sativa L. Mol Breed 19:329-340. https://doi.org/10.1007/s11032-006-9065-7

Ranawake AL, Amarasingha UGS, Rodrigo WDRJ, Rodrigo UTD, Dahanayaka N (2012) Effect of water stress on growth and yield of mung bean (Vigna radiata L). Tropical Agricultural Research and Extension 14:76-80. https://doi.org/10.4038/tare.v14i4.4851

Ratnasekera DP, Subhashi APT (2015) Morpho-physiological response of selected Sri Lankan mungbean (Vigna radiata L.) genotypes to drought stress. J AgriSearch 2:62-66.

Sadhukhan A, Kobayashi Y, Kobayashi Y, Tokizawa M, Yamamoto YY, Iuchi S, Koyama H, Panda SK, Sahoo L (2014) VuDREB2A, a novel DREB2-type transcription factor in the drought-tolerant legume cowpea, mediates DREdependent expression of stress responsive genes and confers enhanced drought 
resistance in transgenic Arabidopsis. Planta 240:645-664. https://doi.org/10.1007/s00425-014-2111-5

Sakuma Y, Maruyama K, Osakabe Y, Qin F, Seki M, Shinozaki K, YamaguchiShinozaki K (2006) Functional analysis of an Arabidopsis transcription factor, DREB2A, involved in drought responsive gene expression. Plant Cell 18:12921309. https://doi.org/10.1105/tpc.105.035881

Sanchez DH, Schwabe F, Erban A, Udvardi MK, Kopka J (2012) Comparative metabolomics of drought acclimation in model and forage legumes. Plant Cell Environ. 35:136-49. https://doi.org/10.1111/j.1365-3040.2011.02423.x

Singh B, Bohra A, Mishra S, Joshi R, Pandey S (2015) Embracing new-generation 'omics' tools to improve drought tolerance in cereal and food- legume crops. Biol Plant 59:413-428. https://doi.org/10.1007/s10535-015-0515-0

van Zonneveld M, Rakha M, Tan SY, Chou Y-Y, Chang C-H, Yen J-Y, Schafleitner R, Nair R, Naito K, Solberg S (2020) Mapping patterns of abiotic and biotic stress resilience uncovers conservation gaps and breeding potential of Vigna wild relatives. Scientific Reports 10:2111. https://doi.org/10.1038/s41598-020-586468

Vu HTT, James AT, Lawn RJ, Bielig LM, Kilian A (2015) Use of DArT molecular markers for QTL analysis of drought-stress responses in soybean. I. Phenotypic evaluation of traits. Crop Pasture Sci 66:802-816. https://doi.org/10.1071/CP14303

Yang G, Yu L, Zhang K, Zhao Y, Guo Y, Gao C (2017) A ThDREB gene from Tamarix hispida improved the salt and drought tolerance of transgenic tobacco and T. hispida. Plant Physiol Biochem 113:187-197. https://doi.org/10.1016/j.plaphy.2017.02.007

Yoshida T, Mogami J, Yamaguchi-Shinozaki K (2014) ABA-dependent and ABAindependent signaling in response to osmotic stress in plants. Curr Opin Plant Biol 21:133-139. https://doi.org/10.1016/j.pbi.2014.07.009 
Figures
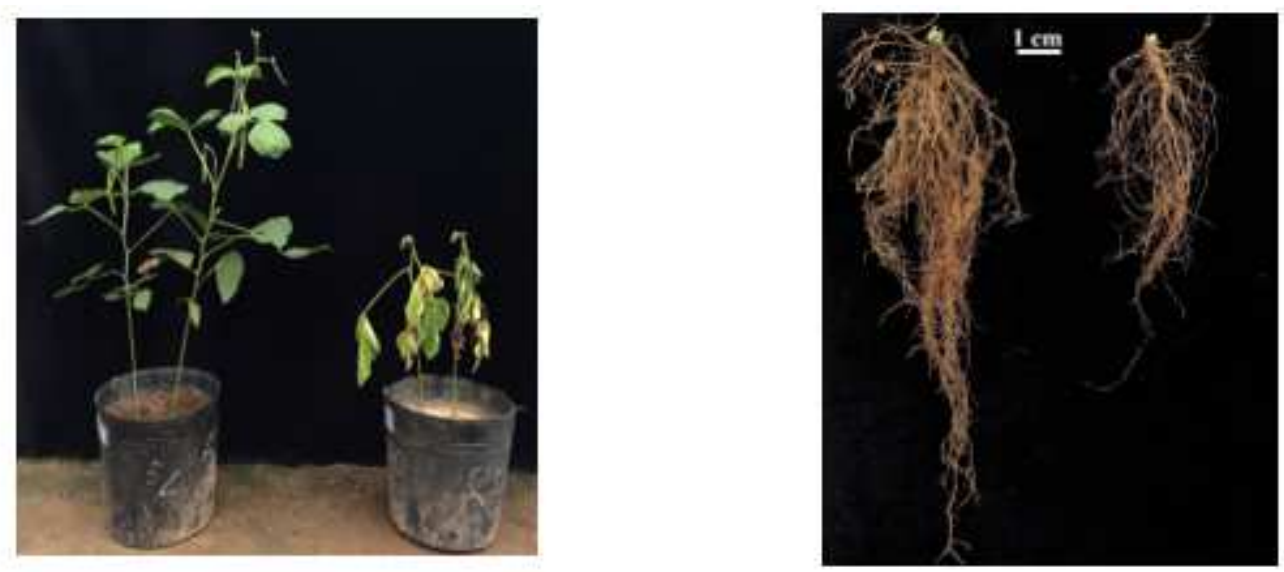

A
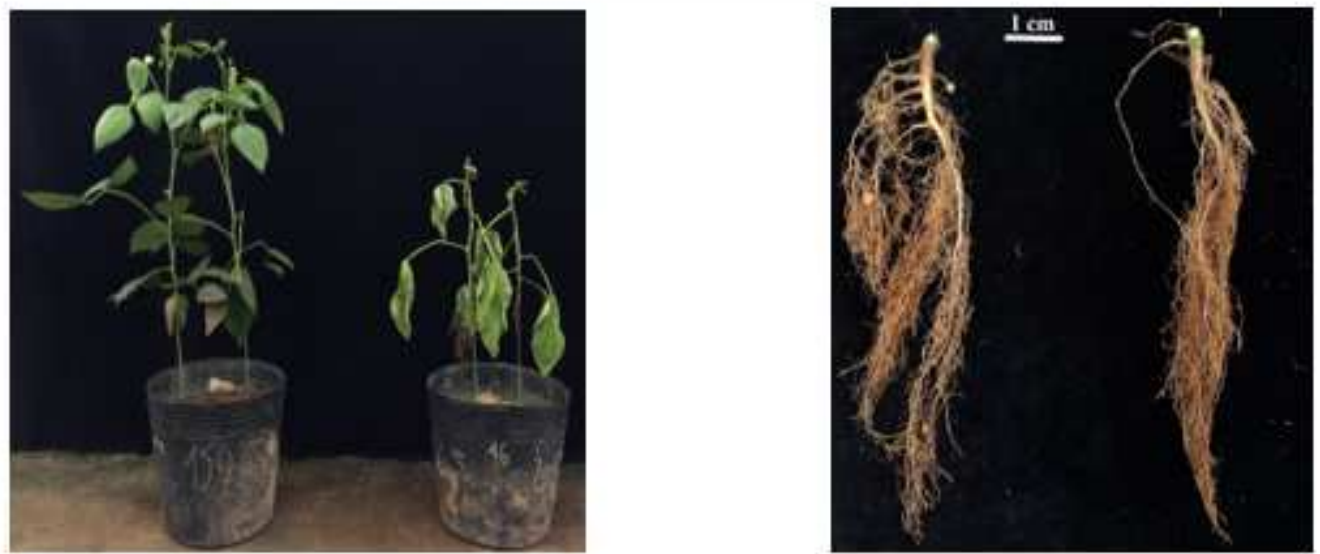

B

\section{Figure 1}

Severe symptoms of plants and roots after 20 days exposed to drought at the flowering stage on two mung bean cultivars, DX208 (A) and Tam Thanh Hoa (B) (left: control, right: drought stress) 


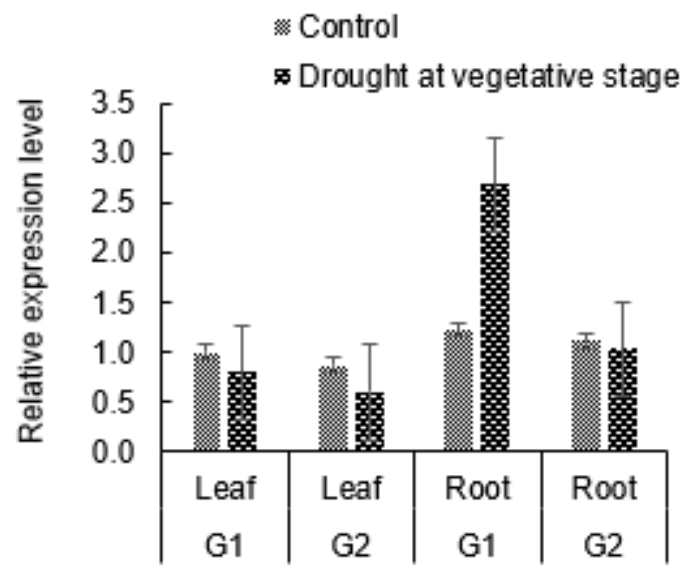

a. 8 days

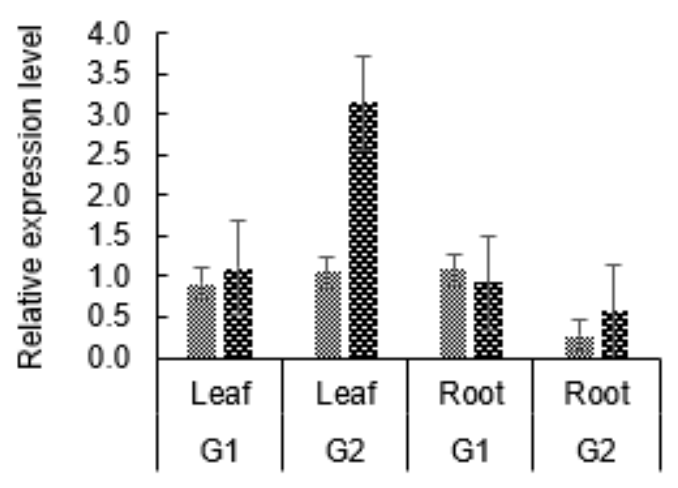

c. 15 days

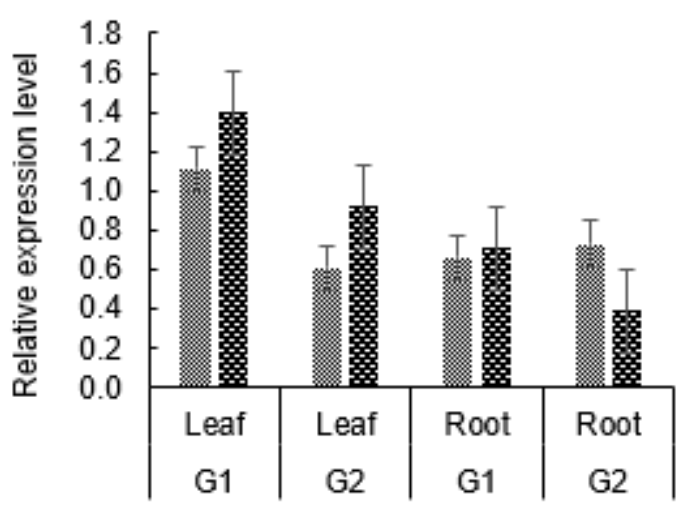

b. 12 days

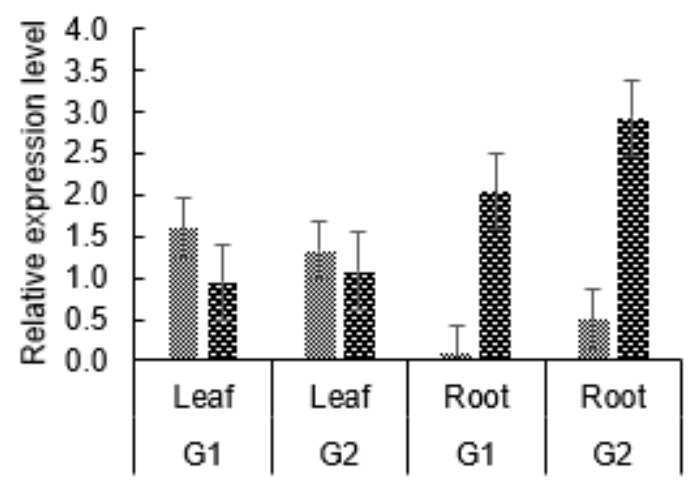

d. 20 days

Figure 2

Relative expression of VrDREB2A gene in leaves and roots of two mung bean cultivars, DX208 (G1) and Tam Thanh Hoa (G2), exposed to drought at the vegetative stage for (a) 8, (b) 12, (c) 15, (d) 20 days in comparison with the control 


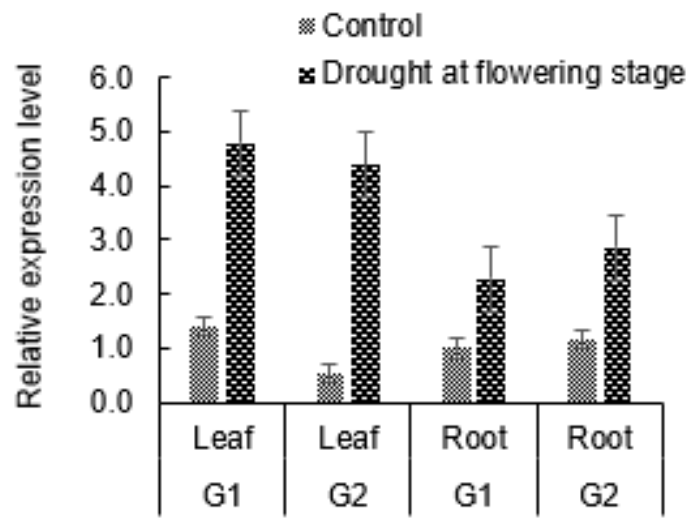

a. 8 days

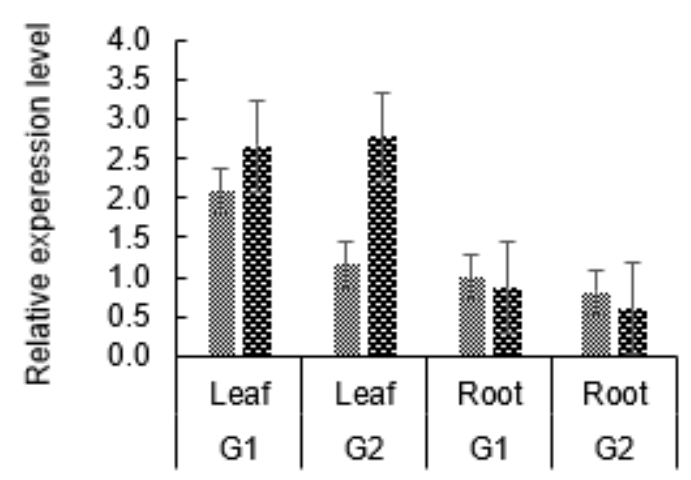

C. 15 days

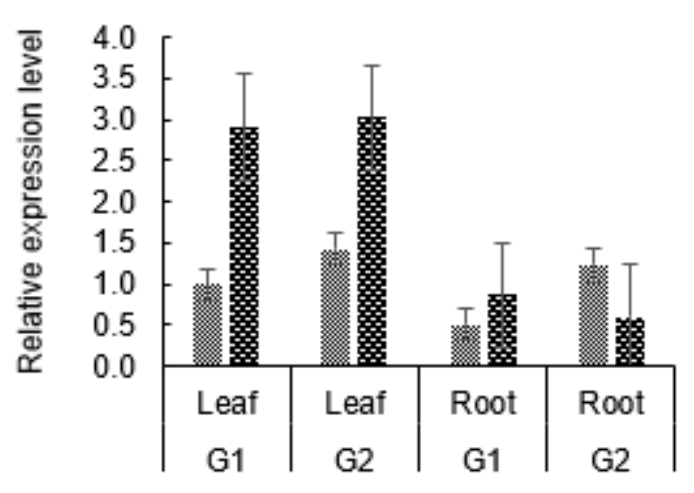

b. 12 days

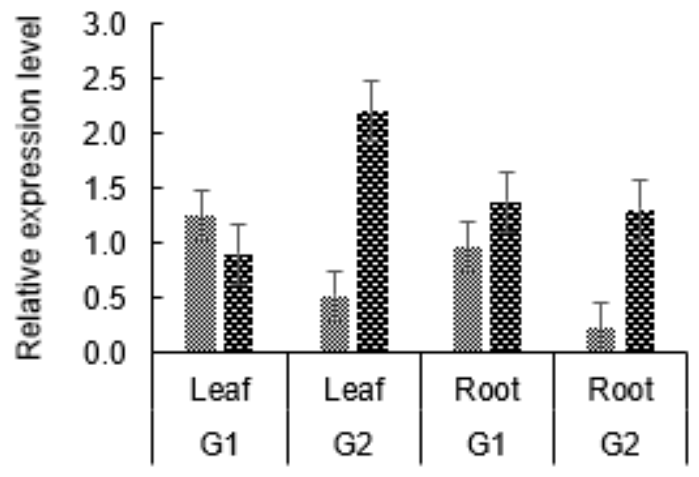

d. 20 days

Figure 3

Relative expression of VrDREB2A gene in leaves and roots of two mung bean cultivars, DX208 (G1) and Tam Thanh Hoa (G2), exposed to drought at the flowering stage for (a) 8, (b) 12, (c) 15, (d) 20 days in comparison with the control 